\title{
Role of the CNS Melanocortin System in the Response to Overfeeding
}

\author{
Mary M. Hagan, ${ }^{1}$ Paul A. Rushing, ${ }^{1}$ Michael W. Schwartz, ${ }^{2}$ Keith A. Yagaloff, ${ }^{3}$ Paul Burn, ${ }^{3}$ \\ Stephen C. Woods, ${ }^{1}$ and Randy J. Seeley ${ }^{1}$ \\ ${ }^{1}$ Department of Psychiatry, University of Cincinnati Medical Center, Cincinnati, Ohio 45267-0559, 2Department of \\ Medicine and Puget Sound Veterans Administration Health Care System, Harborview Medical Center, University of \\ Washington, Seattle, Washington, 98195, and '3epartment of Metabolic Diseases, Hoffman-La Roche, Inc., Nutley, \\ New Jersey 07110
}

The voluntary suppression of food intake that accompanies involuntary overfeeding is an effective regulatory response to positive energy balance. Because the pro-opiomelanocortin (POMC)-derived melanocortin system in the hypothalamus promotes anorexia and weight loss and is an important mediator of energy regulation, we hypothesized that it may contribute to the hypophagic response to overfeeding. Two groups of rats were overfed to 105 and $116 \%$ of control body weight via a gastric catheter. In the first group, in situ hybridization was used to measure POMC gene expression in the rostral arcuate (ARC). Overfeeding increased POMC mRNA in the ARC by $180 \%$ relative to levels in control rats. For rats in the second group, the overfeeding was stopped, and they were infused intracerebrov- entricularly with SHU9119 (SHU), a melanocortin (MC) antagonist at the MC3 and MC4 receptor, or vehicle. Although SHU $(0.1 \mathrm{nmol})$ had no effect on food intake of control rats, intake of overfed rats increased by $265 \%$ relative to CSF-treated controls. This complete reversal of regulatory hypophagia not only maintained but actually increased the already elevated weight of overfed rats, whereas CSF-treated overfed rats lost weight. These results indicate that CNS MCs mediate hypophagic signaling in response to involuntary overfeeding and support the hypothesis that MCs are important in the central control of energy homeostasis.

Key words: POMC; leptin; $\alpha$-melanocyte stimulating hormone; obesity; food intake; energy balance
The matching of caloric intake to caloric expenditure is a process required for the stability of body adipose stores that is performed primarily by the CNS. Involuntary overfeeding, where calories are provided in excess of caloric expenditure by direct infusion into the stomach, produces a state of positive energy marked by increased body weight and a $>90 \%$ decrease in voluntary food intake. Once the overfeeding regimen is terminated, animals continue to suppress their intake until normal body weight is restored (Bernstein et al., 1975; Seeley et al., 1996a). This ability of the body to suppress eating and lose weight after sustained periods of positive energy balance represents a critical response for successful regulation of body weight.

Considerable evidence implicates the hypothalamic melanocortin (MC) system in the control of food intake and body weight. Melanocortins are cleavage products of pro-opiomelanocortin (POMC). Neurons in the arcuate nuclei of the hypothalamus (ARC) that synthesize POMC project to areas such as the paraventricular nucleus of the hypothalamus (PVN), where food intake is regulated. $\alpha$-Melanocyte stimulating hormone $(\alpha$ $\mathrm{MSH}$ ), an endogenous MC that binds with high affinity to MC3 and MC4 receptors, is expressed in PVN neurons (Eskay et al., 1979; Mountjoy et al., 1992). Central administration of $\alpha$-MSH and its agonist MTII in rats reduces food intake (Fan et al., 1997;

Received Oct. 26, 1998; revised Dec. 21, 1998; accepted Jan. 7, 1999

This work was supported by grants from National Institutes of Health (DK54080, DK54890, DK17844, NS32273). We also thank Brian Seeley and Kathi Blake for their assistance in the data collection.

Correspondence should be addressed to Dr. Mary M. Hagan, College of Medicine, Department of Psychiatry, University of Cincinnati Medical Center, P.O. Box 670559, Cincinnati, OH 45267-0559.

Copyright (ㄷ) 1999 Society for Neuroscience $\quad 0270-6474 / 99 / 192362-06 \$ 05.00 / 0$
Ludwig et al., 1998; Thiele et al., 1998). Conversely, central administration of the MC receptor antagonists SHU9119 (SHU) (Fan et al., 1997; Seeley et al., 1997b) and HSO14 (Kask et al., 1998) stimulate food intake. The MC4 receptor appears critical to normal body weight homeostasis because its targeted deletion results in obesity and hyperphagia (Huszar et al., 1997).

Accordingly, we hypothesized that MC signaling may mediate the reduced food intake that follows overfeeding. Overfeeding produces increased adipose stores and raises plasma leptin levels (Frederich et al., 1995a) and leptin mRNA (Frederich et al., 1995a; Harris et al., 1996; Cha and Jones, 1998). Circulating leptin signals the CNS to decrease intake to regulate body fat stores (Zhang et al., 1994; Frederich et al., 1995b; Schwartz et al., 1996) and appears to be an important determinant of hypothalamic MC activity. Leptin receptors are found on ARC POMC neurons (Cheung et al., 1997), POMC expression in the ARC is increased by leptin (Schwartz et al., 1997; Thornton et al., 1997; Mizuno et al., 1998), and when CNS MC receptors are antagonized, the ability of leptin to inhibit food intake is abolished (Seeley et al., 1997b).

We therefore proposed that the hypophagia and body weight loss observed after involuntary overfeeding is caused by a cascade of events beginning with elevated levels of negative feedback hormones such as leptin that activate the hypothalamic MC system, which triggers an anorexic response. To test this hypothesis, we assessed the effect of involuntary overfeeding on hypothalamic POMC gene expression and determined whether a centrally administered $\mathrm{MC} 3 / 4$ receptor antagonist, SHU, is able to reverse the inhibited food intake and body weight loss induced by involuntary overfeeding. 


\section{MATERIALS AND METHODS}

Experiment 1: effect of involuntary overfeeding on arcuate nucleus POMC mRNA levels

Male Long-Evans rats $(n=7)$ were overfed via gastric catheter with a diet consisting of sweetened condensed milk diluted with an equal volume of distilled water $(2.1 \mathrm{kcal} / \mathrm{ml})$ and vitamins (Polyvisol with iron). Rats were overfed starting with two meals of $8 \mathrm{ml}$ each and increasing to five meals of $13 \mathrm{ml}$ each on the final $3 \mathrm{~d}$. The volume of diet was increased gradually in increments to prevent unnecessary stress and adverse gastrointestinal effects such as diarrhea. Chow was always available for voluntary intake. Rats were kept on this regimen until they reached a mean body weight of $105 \%$ of the body weight of the control group $(n=8)$, which was treated identically but infused with equal volumes of physiological saline instead of the milk diet. This weight that represented a significantly higher body weight than that of the controls was achieved after $10 \mathrm{~d}$ of overfeeding. On day 11, the overfed rats were euthanized by $\mathrm{CO}_{2}$ inhalation and decapitated for collection of brain tissue. Other parameters of these rats (food intake, body weight change, plasma glucose, corticosterone, insulin, and hypothalamic corticotropin releasing hormone (CRH), arginine vasopressin, and NPY mRNA) were reported previously (Seeley et al., 1996a). For the present experiment we assessed POMC mRNA in the ARC.

In situ hybridization. Brains were frozen and sectioned at $14 \mu \mathrm{m}$ with a cryostat. Slides for in situ hybridization (ISH) to POMC mRNA were taken from the rostral ARC region by an investigator blind to treatment conditions. A riboprobe complementary to rat POMC mRNA (a generous gift of Dr. Robert Steiner, University of Washington, Seattle, WA) was labeled with ${ }^{33} \mathrm{P}$ as described previously (Schwartz et al., 1997). Quantitation of POMC mRNA hybridization was performed by computer densitometry of ISH autoradiograms. Values of POMC mRNA hybridization for each animal were determined as the mean of six to eight sections. The data are presented as the product of hybridization area $\times$ density as described (Schwartz et al., 1997). This method of quantification does not distinguish change in mRNA per cell from number of cells expressing message but rather provides an index of overall mRNA levels.

Statistical analysis. Between-group mean values of POMC mRNA were compared with an unpaired $t$ test (for two-group comparisons). Significance level was set at $p<0.05$.

\section{Experiment 2: effect of intracerebroventricular melanocortin- receptor antagonist on overfeeding-induced hypophagia}

Subjects and surgery. Forty male Long-Evan rats (260-280 gm) were individually housed in a temperature-controlled environment $\left(22^{\circ} \mathrm{C}\right)$ with a $12 \mathrm{hr}$ light/dark cycle. Pelleted rat chow and tap water were available at all times except where noted. Rats were anesthetized with sodium pentobarbital $(60 \mathrm{mg} / \mathrm{kg})$ and given a prophylactic injection of gentamicin (40 mg/kg, i.p.). A gastric catheter was surgically implanted as described previously (Seeley et al., 1997a). In addition, a cannula was stereotaxically implanted into the third cerebral ventricle (i3vt) as described previously (Seeley et al., 1996b). After 1 week of recovery from surgery, placement of i3vt cannulae was confirmed by the drinking response to infusion of $10 \mathrm{ng}$ angiotensin II in saline while the animals were water-repleted. The criterion for inclusion in the study was drinking $\geq 5 \mathrm{ml}$ of water in $1 \mathrm{hr}$.

Experimental protocol. Rats (now 340-380 gm) were assigned to two weight-matched groups, one to receive gastric infusions of a high-calorie (HC) diet and the other equal volumes of isotonic saline. Unlimited chow was available at all times. To achieve a higher body weight difference (110-116 vs $105 \%$ of control weight) in a reasonable amount of time, a different $\mathrm{HC}$ diet was used. The diet was formulated by Akiyama et al. (1996) and contained 50\% fat (from corn oil), $25 \%$ protein (from lactalbumin hydrosylate), and 25\% carbohydrate (from dextrose). Polyvisol with iron was included as a vitamin supplement. Meals were delivered into the stomach via a multi-head peristaltic pump and Tygon tubing. Over days 1-16, gastric inf usions were increased incrementally from one meal of $10 \mathrm{ml}$ on the first day to five meals of $15 \mathrm{ml}$ each on the last $2 \mathrm{~d}$. Control rats were infused with equal volumes of isotonic saline. Infusions were stopped after day 16, at which time the overfed and control rats were weight-matched into two subgroups: one overfed subgroup and one control subgroup to be infused with $0.5 \mathrm{nmol} \mathrm{SHU}$ (Hoffman-La Roche, Nutley, NJ) and the other overfed and control subgroups to be

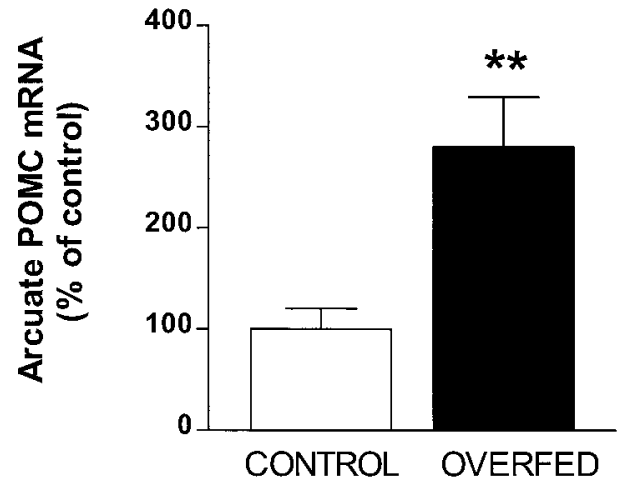

Figure 1. Mean (+ SE) mRNA for POMC in the arcuate nucleus of the hypothalamus for control rats and rats overfed to $105 \%$ of body weight of controls. Values represent area $\times$ density measures derived from computer densitometry. ${ }^{* *} p<0.01$.

inf used with vehicle (synthetic CSF) in a $2 \mu$ l volume over 1 min. These SHU and CSF inf usions were given at the onset of dark on day 17, $24 \mathrm{hr}$ after the last diet inf usion. Food containers were removed from the cages and weighed $2 \mathrm{hr}$ before drug infusions and replaced with premeasured amounts after drug infusions. Food intake was measured after 1, 2, 3, 4, and $24 \mathrm{hr}$, and body weight was recorded after $24 \mathrm{hr}$.

The results of Experiment 1 suggested that MCs may be biologically important in responses to overfeeding because POMC mRNA was elevated in overfed rats. Therefore, melanocortin agonist action might presumably also be higher, rendering a lower dose of antagonist effective. To test this possibility, on day 19 the overfeeding regimen was reinitiated on the overfed animals for another $6 \mathrm{~d}$, starting with three meals of $15 \mathrm{ml}$ each and ending with five $15 \mathrm{ml}$ meals on the final day. As before, the control rats that received equal amounts of saline intragastrically, continued to receive saline. At the end of $6 \mathrm{~d}$ of gastric inf usions, the overfed rats were again weight-matched into two subgroups, one to receive a lower dose of SHU $(0.1 \mathrm{nmol})$ and the other to receive CSF. Likewise, the control rats were weight-matched and subdivided into two groups, one to receive SHU $(0.1 \mathrm{nmol})$ and the other to receive CSF. In this way, previous experience with i3vt infusion high-dose SHU or CSF was randomized across rats. Again, gastric inf usions were stopped, and $24 \mathrm{hr}$ elapsed before SHU and CSF infusions were administered at the onset of dark. Body weights and food intakes were measured as described above. This testing procedure was repeated $24 \mathrm{hr}$ after the first drug infusion. Furthermore, to explore the degree to which SHU could reverse hypophagia and maintain obesity in the overfed animal, inf usions of $0.1 \mathrm{nmol} \mathrm{SHU}$ or CSF were repeated again with $24 \mathrm{hr}$ in between for a total of three infusions across 3 consecutive days.

Statistical analysis. One-way ANOVAs with four levels (overfed/SHU vs overfed/CSF vs control/SHU vs control/CSF) were conducted for each hour of intake. Significant group differences were further analyzed using Tukey's highly significant test. Interactions, where noted, were derived from a two-way ANOVA (overfed or control vs SHU or CSF), and paired-samples $t$ tests were used to analyze differences within groups. ANOVAs and post hoc tests both used significance levels set at $p<0.05$.

\section{RESULTS}

\section{Experiment 1: in situ hybridization results of POMC MRNA}

As in previous experiments, hybridization of POMC mRNA was readily detected in the ARC, but not in other brain areas, in film autoradiograms of coronal brain sections. Among overfed rats, POMC mRNA hybridization was visibly increased, and as depicted in Figure 1, the level of mRNA for POMC in the ARC was elevated by $180 \%$ in the overfed group relative to control levels $(p=0.002)$. 
A

Figure 2. A, Mean ( $\pm \mathrm{SE}$ ) daily spontaneous kilocalories of intake for the overfed and control group during the course of the first overfeeding episode. $B$, Mean $( \pm \mathrm{SE})$ body weight for the overfed and control group over the course of the first and second overfeeding episodes. ${ }^{* *} p<0.001$.

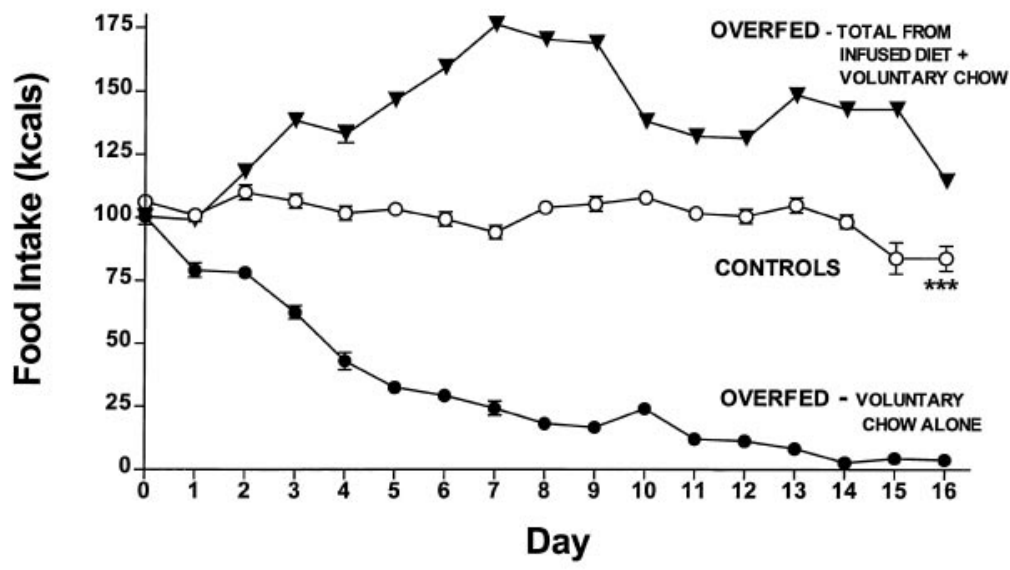

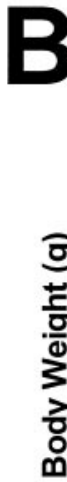

\section{Experiment 2: changes in food intake and body weight} during the overfeeding regimen

After $16 \mathrm{~d}$ of overfeeding (and just before the first test of $0.5 \mathrm{nmol}$ SHU), animals infused with the HC diet were receiving $146 \%$ of control calorie intake, and as depicted in Figure $2 A$, daily voluntary chow intake of overfed rats was reduced to $3 \%$ of that of the controls $(p<0.001)$. At day 25 (data not shown), which marked the end of the second episode of overfeeding, the overfed animals were receiving $135 \%$ of control calories, and voluntary intake of chow in the overfed rats was $4 \%$ of control intake $(p<0.001)$. As depicted in Figure $2 B$, changes in food intake produced body weight in overfed rats that was $10 \%$ higher than controls infused with equal volumes of saline $(p<0.001)$. By the end of the second overfeeding episode, overfed rats attained a $16 \%$ higher body weight than that of the controls $(p<0.001)$.

\section{Effect of $0.5 \mathrm{nmol}$ SHU9119 on hypophagia and weight}

Infusion of $0.5 \mathrm{nmol} \mathrm{SHU}$ increased $24 \mathrm{hr}$ food intake in control rats as depicted in Figure 3 ( $t$ test, $p<0.01$ ). This dose of SHU also blocked the potent hypophagia observed in the obese, CSFtreated overfed rats $(t$ test, $p<0.05)$, resulting in an increase of food intake ( $t$ test, $p<0.001)$ that was greater than the increase produced by SHU in control rats $(t$ test, $p<0.01)$. This effect
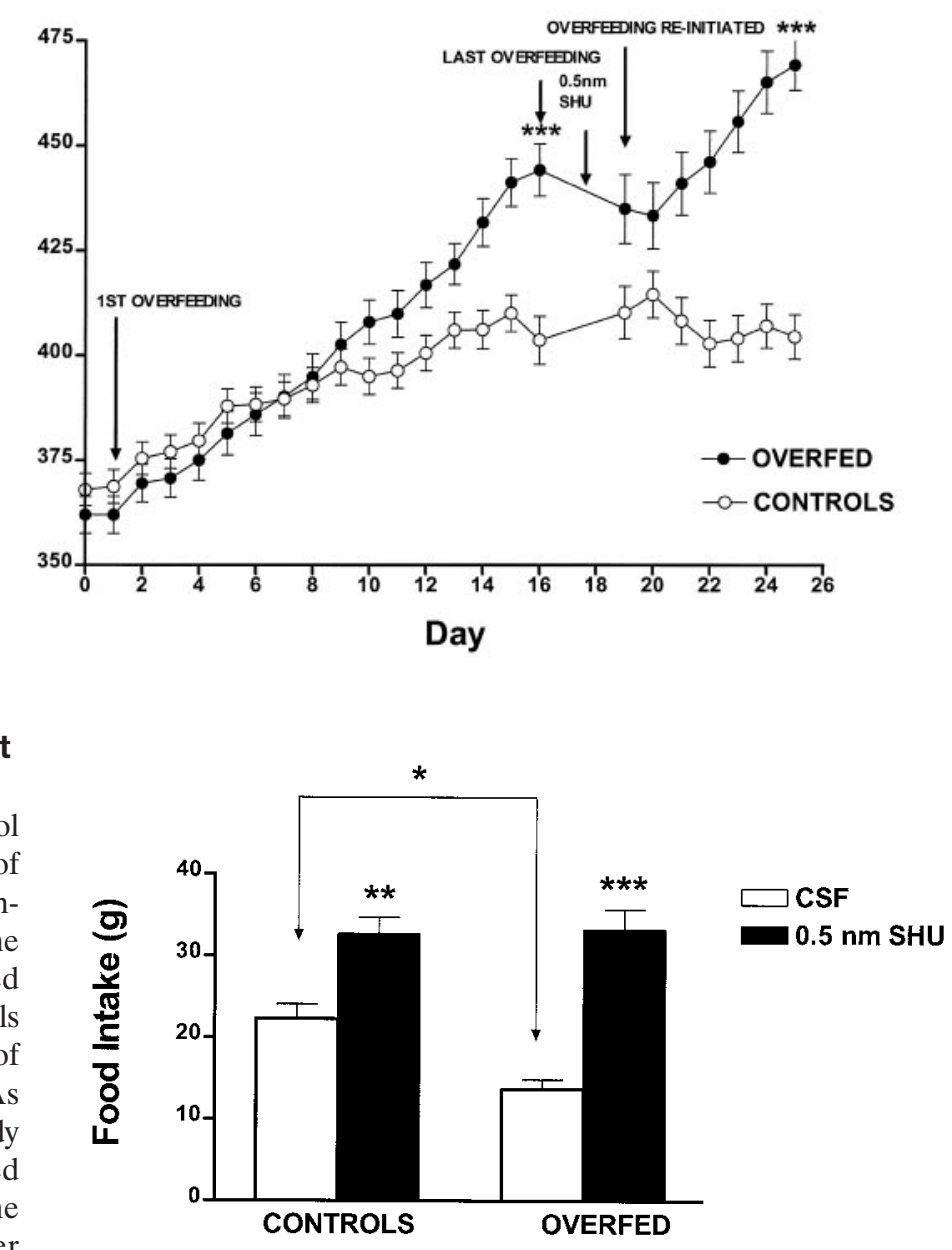

Figure 3. Mean $(+\mathrm{SE}) 24 \mathrm{hr}$ chow intake of rats treated with $0.5 \mathrm{nmol}$ i3vt SHU or CSF vehicle. * $p<0.05 ;{ }^{* *} p<0.01$; ${ }^{* *} p<0.001$.

translated into an intake by overfed rats that matched the intake of lean animals treated with SHU $(33.3 \pm 2.4$ vs $32.7 \pm 2.0 \mathrm{gm}$, respectively). A significant interaction between overfeeding conditions and drug $(p<0.05)$ indicated an increased sensitivity of SHU in overfed animals. Because of this, the same rats were again overfed. 


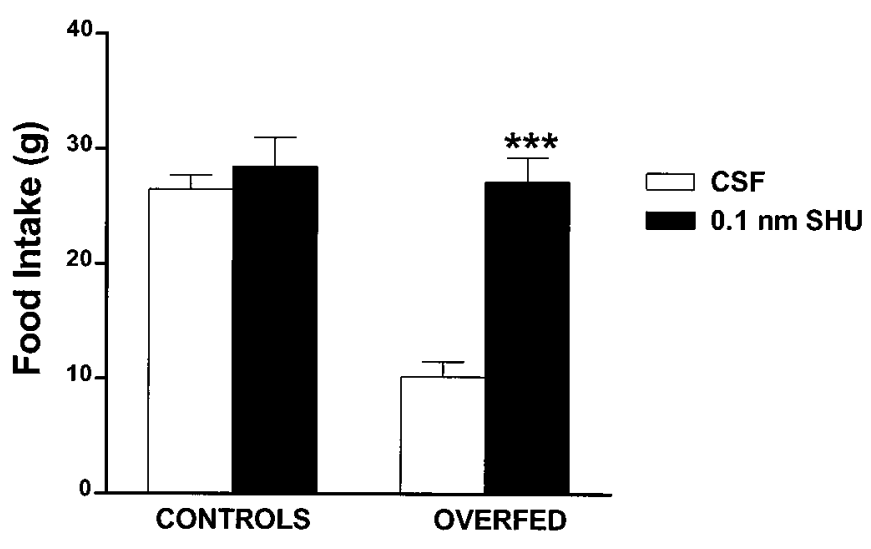

Figure 4. Mean $(+\mathrm{SE})$ grams of $24 \mathrm{hr}$ chow intake of control and overfed rats on the third day of i3vt lower dose $(0.1 \mathrm{nmol})$ SHU or CSF vehicle. ${ }^{* * *} p<0.001$.

\section{Effect of $0.1 \mathrm{nmol}$ SHU9119 on hypophagia and body weight}

Figure 4 depicts the third day of drug infusions on which overfed rats given CSF had reduced food intake relative to controls given CSF (10.2 \pm 1 vs $26.5 \pm 1 \mathrm{gm})$. However, i3vt SHU (0.1 nmol) produced a nonsignificant increase in $24 \mathrm{hr}$ food intake in control animals, and it caused a robust orexigenic effect (137\% of CSFtreated controls) in the overfed rats $(p<0.001)$. As depicted in Figure 5, the increased sensitivity of SHU's orexigenic effect in overfed animals persisted over the subsequent $2 \mathrm{~d}$. By the third day, control animals receiving SHU had a significant increase in $24 \mathrm{hr}$ food intake compared with that of CSF-treated controls. The data in Figure 5 are depicted as percentage of food intakes relative to CSF-treated rats to better illustrate this significant drug (SHU or CSF) by energy-state (overfed vs lean) interaction. As depicted in Figure 6, SHU increased body weight in control rats (from $403.3 \pm 8$ to $427.8 \pm 10 \mathrm{gm} ; t$ test, $p<0.01$ ) and prevented the overfed group from losing weight (weight increased from $468 \pm 12$ to $481 \pm 15$ ), whereas CSF-treated rats lost weight because of overfeeding-induced hypophagia (from $470 \pm 8$ to $448 \pm 1 \mathrm{gm} ; t$ test, $p<.001)$.

\section{DISCUSSION}

The purpose of these experiments was to test the hypothesis that MC activity is increased in involuntarily overfed rats and that this response contributes to the ensuing hypophagia. In the first experiment, the level of mRNA for the MC precursor protein POMC was assessed in the hypothalamus of overfed and control rats. POMC mRNA in the ARC was significantly elevated (an increase of $180 \%$ ) in overfed compared with control animals. Body weight was only elevated by $5 \%$ in these rats. The increased levels of ARC POMC mRNA in response to overfeeding paralleled the increased levels of CRH mRNA in the PVN in the same animals, as reported previously (Seeley et al., 1996a). Because CRH (Krahn and Gosnell, 1988) and POMC post-translational products (ACTH, $\alpha$-MSH) are potent inhibitors of food intake (Poggioli et al., 1986; Schioth et al., 1996), these results suggest that hypothalamic overexpression of $\mathrm{CRH}$ and POMC may mediate the effect of overfeeding to reduce food intake.

In the second experiment, the effect of i3vt administration of a selective MC receptor antagonist was assessed on the hypophagia and body weight loss that occurs after overfeeding. Intragastric overfeeding produced a $97 \%$ suppression of voluntary food intake
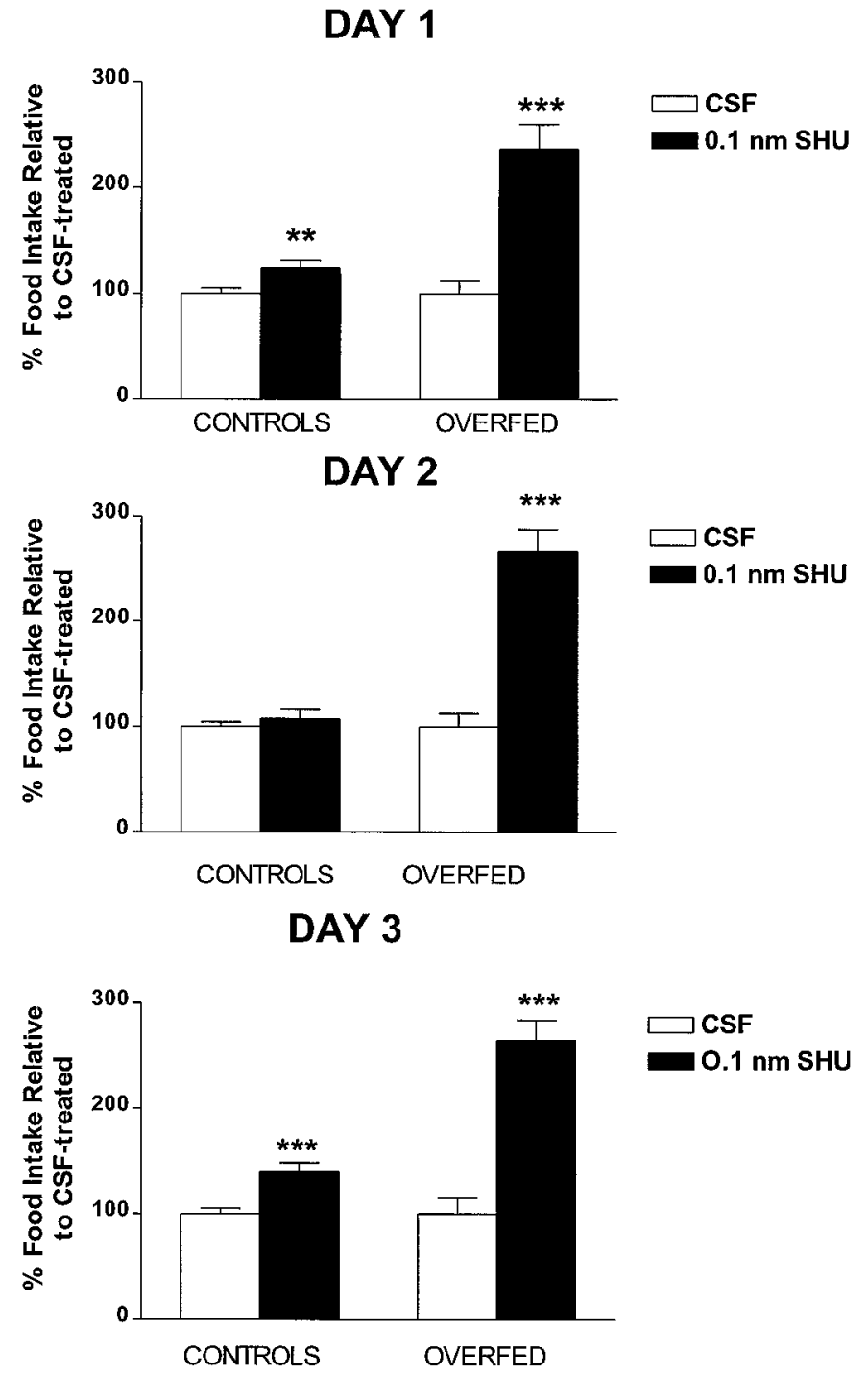

Figure 5. Mean $(+\mathrm{SE}) 24 \mathrm{hr}$ chow intake in animals treated i3vt with 0.1 nmol SHU9119 or CSF vehicle on 3 consecutive days. Error bars represent the percentage of each group's mean control intake. ${ }^{* *} p<0.01$; $* * * p<0.001$.

and increased body weight by $16 \%$. Central inf usion of the higher dose of SHU9119 (0.5 nmol) elicited a $47 \%$ increase in $24 \mathrm{hr}$ food intake in control rats relative to CSF-treated control rats and a $143 \%$ increase of $24 \mathrm{hr}$ intake in overfed animals compared with their hypophagic, overfed controls.

To elucidate what appeared to be a more sensitive response of the overfed animals to $\mathrm{MC}$ antagonism, the rats were again overfed, and a lower dose of SHU9119 (0.1 nmol) was given. Overfed animals responded to SHU with a $137 \%$ increase of food intake, representing a complete reversal of the hypophagia induced by overfeeding. In contrast, this low dose of SHU had no significant effect on food intake in control (nonoverfed) rats. In the overfed group, $3 \mathrm{~d}$ of SHU-induced feeding resulted in the maintenance and even slight increase of these animals' already obese weight. In contrast, overfed animals not treated with SHU lost weight precipitously because of voluntary low food intake.

Taken together, these findings suggest that increased signaling at $\mathrm{MC}$ receptors is an important component of the hypothalamic response to restore energy balance. The long-term feeding ma- 


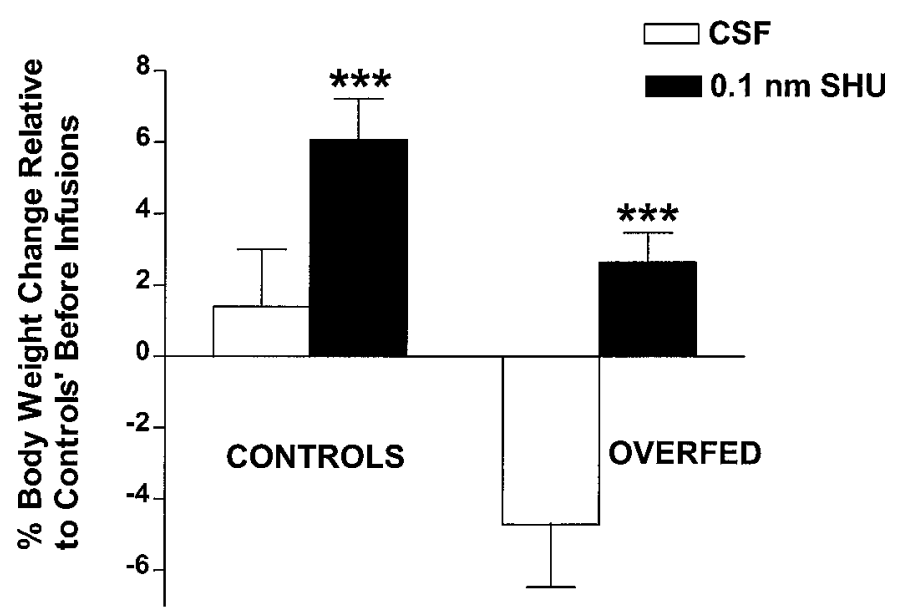

Figure 6. Mean (+ SE) of the percentage body weight gained or lost after $3 \mathrm{~d}$ of $0.1 \mathrm{nmol}$ i3vt SHU infusions relative to the weight of each group's CSF-treated animals before the infusion. Percentages were derived from the formula $\{[\%$ body weight gain or loss per animal $]$ - (mean $\%$ body weight gain for CSF-treated groups) $\} \times 100 .{ }^{* * *} p<0.001$.

nipulations that were used in these experiments and the robust effects of SHU in the overfed animals support increased body weight as a stimulus of MC effects in the hypothalamus. However, there was also evidence that excess food intake and not just excess body weight provides this stimulus. Specifically, in Experiment 1, a significant elevation in POMC mRNA was observed in rats that were only $5 \%$ heavier than lean rats, suggesting that food intake and not body weight changes promotes MC effects. Also, SHU increased food intake in lean rats but not nearly to the extent that it did in the overfed rats. Therefore, it appears that MC-mediated effects are promoted by food intake, but their biological role in promoting energy balance may be more salient in conditions that threaten energy balance, such as obesity.

A major peripheral signal of positive energy and one that may be communicating with a central MC system to regulate food intake and body weight in response to overfeeding is leptin (Zhang et al., 1994; Schwartz et al., 1996). Considerable evidence suggests that MC receptor signaling may be mediating leptin's anorectic effects. The leptin receptor is expressed in ARC POMC neurons (Cheung et al., 1997), and expression of POMC mRNA in the ARC is increased by i3vt administration of leptin (Schwartz et al., 1997). Mice deficient in or resistant to leptin (ob/ob and $d b / d b$ mice) have a major reduction of ARC POMC mRNA (Schwartz et al., 1997). In addition, the anorectic effects of leptin, and leptin-induced c-fos expression in the PVN, are both blocked in rats pretreated with 0.5 nmol SHU9119 (Seeley et al., 1997b), the same dose found here to block overfeeding-induced hypophagia.

These data are consistent with the hypothesis that leptin activation of MC receptor reduces food intake when animals have been rendered obese involuntarily. The pathway would be (1) activation of leptin receptors on POMC neurons in the ARC by increased circulating leptin caused by overfeeding, and (2) activation of these neurons to release POMC-derived $\alpha$-MSH (or some other endogenous MC) that binds and activates MC3/4-R (Adan et al., 1994) in the PVN, ventromedial, dorsomedial, or lateral hypothalamic nuclei (Mountjoy et al., 1994) to (3) initiate a cascade of events that decreases food intake (Seeley et al., 1997b; Mizuno et al., 1998; Woods et al., 1998).

MC regulation of energy balance may also include extra- hypothalamic sites and negative-energy feedback signals other than leptin. For example, POMC and $\alpha-\mathrm{MSH}$ are expressed in the commissural nucleus of the solitary tract (Palkovits et al., 1987; Bronstein et al., 1992). Recently, Grill et al. (1999) observed increased $24 \mathrm{hr}$ intake and body weight in rats injected in the lateral or fourth ventricle with SHU9119 (0.25-1.0 nmol), doses that were comparable to those used in the present experiment. Because the response to SHU administration in the fourth ventricle was equipotent with the response to i3vt injection, it appears that blockade of $\mathrm{MC}$ receptors in either the brainstem or the forebrain can elicit feeding. The role of the brainstem MC system in the response to overfeeding warrants additional study.

Another negative feedback signal that might cause MC receptor activation is insulin, which is increased $25 \%$ in overfed animals compared with controls (Seeley et al., 1996a). ARC POMC mRNA has recently been found to be decreased in insulindeficient rats and to normalize with insulin administration, and POMC mRNA is also increased in normal rats treated systemically with insulin (Kim et al., 1999). Finally, there is evidence to suggest that leptin and insulin may not work independently but rather in an interactive capacity to regulate the effects of positive energy (Malmstrom et al., 1996; Wabitsch et al., 1996).

In summary, the present results indicate that involuntary overfeeding is associated with increased POMC mRNA expression in the ARC and that the overfeeding-induced hypophagia is disrupted by MC3/4 blockade. These findings, therefore, extend the working model of MCs to include involuntary, induced obesity. In obesity, the negative feedback system to limit food intake and body weight that involves CNS MC may be compromised. Further understanding of the peripheral and central mechanisms that are responsive to positive energy balance hold important implications for human obesity. In particular, therapeutics targeted at MC functioning may be especially promising.

\section{REFERENCES}

Adan RA, Cone RD, Burbach JP, Gispen WH (1994) Differential effects of melanocortin peptides on neural melanocortin receptors. Mol Pharmacol 46:1182-1190.

Akiyama T, Tachibana I, Shirohara H, Watanabe N, Otsuki M (1996) High-fat hypercaloric diet induces obesity, glucose intolerance and hyperlipidemia in normal adult male Wistar rat. Diabetes Res Clin Pract 31:27-35.

Bernstein IL, Lotter EC, Kulkosky PJ, Porte Jr D, Woods SC (1975) Effect of force-feeding upon basal insulin levels of rats. Proc Soc Exp Biol Med 150:546-548.

Bronstein DM, Schafer MK, Watson SJ, Akil H (1992) Evidence that beta-endorphin is synthesized in cells in the nucleus tractus solitarius: detection of POMC mRNA. Brain Res 587:269-275.

Cha MC, Jones PJ (1998) Dietary fat type and energy restriction interactively influence plasma leptin concentration in rats. J Lipid Res 39:1655-1660.

Cheung CC, Clifton DK, Steiner RA (1997) Proopiomelanocortin neurons are direct targets for leptin in the hypothalamus. Endocrinology 138:4489-4492.

Eskay RL, Giraud P, Oliver C, Brown MJ (1979) Distribution of alphamelanocyte-stimulating hormone in the rat brain: evidence that alphaMSH-containing cells in the arcuate region send projections to extrahypothalamic areas. Brain Res 178:55-67.

Fan W, Boston BA, Kesterson RA, Hruby VJ, Cone RD (1997) Role of melanocortinergic neurons in feeding and the agouti obesity syndrome. Nature 385:165-168.

Frederich RC, Hamann A, Anderson S, Lollmann B, Lowell BB, Flier JS (1995a) Leptin levels reflect body lipid content in mice: evidence for diet-induced resistance to leptin action. Nat Med 1:1311-1314.

Frederich RC, Lollmann B, Hamann A, Napolitano-Rosen A, Kahn BB, Lowell BB, Flier JS (1995b) Expression of OB mRNA and its encoded protein in rodents. J Clin Invest 96:1658-1663.

Grill HJ, Ginsberg AB, Seeley RJ, Kaplan JM (1999) Brainstem appli- 
cation of melanocortin receptor ligands produces long-lasting effects on feeding and body weight. J Neurosci 18:10128-10135.

Harris RB, Ramsay TG, Smith SR, Bruch RC (1996) Early and late stimulation of ob mRNA expression in meal-fed and overfed rats. J Clin Invest 97:2020-2026.

Huszar D, Lynch CA, Fairchild-Huntress V, Dunmore JH, Fang Q, Berkemeier LR, Gu W, Boston BA, Cone RD, Smith FJ, Campfield LA, Burn P, Lee F (1997) Targeted disruption of the melanocortin-4 receptor results in obesity in mice. Cell 88:131-141.

Kask A, Rago L, Mutulis F, Pahkla R, Wikberg JE, Schioth HB (1998) Selective antagonist for the melanocortin 4 receptor (HSO14) increases food intake in free-feeding rats. Biochem Biophys Res Commun 245: 90-93

Kim EM, Grace MK, Welch CC, Billington CJ, Levine AS (1999) STZ-induced diabetes decreases and insulin normalizes POMC mRNA in arcuate nucleus and pituitary in rats. Am J Physiol, in press.

Krahn DD, Gosnell BA (1988) Behavioral effects of corticotropinreleasing factor: localization and characterization of central effects. Brain Res 443:63-69.

Ludwig DS, Mountjoy KG, Tatro JB, Gillette JA, Frederich RC, Flier JS, Maratos-Flier E (1998) Melanin-concentrating hormone: a functional melanocortin antagonist in the hypothalamus. Am $\mathrm{J}$ Physiol 274:E627-E633.

Malmstrom R, Taskinen MR, Karonen SL, Yki-Jarvinen H (1996) Insulin increases plasma leptin concentrations in normal subjects and patients with NIDDM. Diabetologia 39:993-996.

Mizuno TM, Kleopoulos SP, Bergen HT, Roberts JL, Priest CA, Mobbs CV (1998) Hypothalamic pro-opiomelanocortin mRNA is reduced by fasting in ob/ob and $\mathrm{db} / \mathrm{db}$ mice, but is stimulated by leptin. Diabetes 47:294-297.

Mountjoy KG, Robbins LS, Mortrud MT, Cone RD (1992) The cloning of a family of genes that encode the melanocortin receptors. Science 257:1248-1251.

Mountjoy KG, Mortrud MT, Low MJ, Simerly RB, Cone RD (1994) Localization of the melanocortin-4 receptor (MC4-R) in neuroendocrine and autonomic control circuits in the brain. Mol Endocrinol 8:1298-1308.

Palkovits M, Mezey E, Eskay RL (1987) Pro-opiomelanocortin-derived peptides (ACTH/beta-endorphin/alpha-MSH) in brainstem baroreceptor areas of the rat. Brain Res 436:323-338.

Poggioli R, Vergoni AV, Bertolini A (1986) ACTH-(1-24) and alpha-
MSH antagonize feeding behavior stimulated by kappa opiate agonists. Peptides 7:843-848.

Schioth HB, Muceniece R, Wikberg JE (1996) Characterization of the melanocortin 4 receptor by radioligand binding. Pharmacol Toxicol 79:161-165.

Schwartz MW, Peskind E, Raskind M, Nicolson M, Moore J, Morawiecki A, Boyko EJ, Porte DJ (1996) Cerebrospinal fluid leptin levels: relationship to plasma levels and to adiposity in humans. Nat Med 2:589-593.

Schwartz MW, Seeley RJ, Weigle DS, Burn P, Campfield LA, Baskin DG (1997) Leptin increases hypothalamic proopiomelanocortin (POMC) mRNA expression in the rostral arcuate nucleus. Diabetes 46:2119-2123.

Seeley RJ, Matson CA, Chavez M, Woods SC, Schwartz MW (1996a) Behavioral, endocrine and hypothalamic responses to involuntary overfeeding. Am J Physiol 271:R819-R823.

Seeley RJ, van Dijk G, Campfield LA, Smith FJ, Burn P, Nelligan JA, Bell SM, Baskin DG, Woods SC, Schwartz MW (1996b) Intraventricular leptin reduces food intake and body weight of lean rats but not obese zucker rats. Horm Metab Res 28:664-668.

Seeley RJ, Sharon L, Woods SC (1997a) The effect of intragastric ethanol on meal size in rats. Pharmacol Biochem Behav 56:379-382.

Seeley RJ, Thiele TE, van Dijk G, Baskin DG, Yagaloff KA, Fisher SL, Burn P, Schwartz MW (1997b) Melanocortin receptors in leptin effects. Nature 390:349.

Thiele TE, van Dijk G, Yagaloff KA, Fisher SL, Schwartz MW, Burn P, Seeley RJ (1998) Central infusion of melanocortin agonist MTII in rats: assessment of c-Fos expression and taste aversion. Am J Physiol 274:R248-R254.

Thornton JE, Cheung CC, Clifton DK, Steiner RA (1997) Regulation of hypothalamic proopiomelanocortin mRNA by leptin in ob/ob mice. Endocrinology 138:5063-5066.

Wabitsch M, Jensen PB, Blum WF, Christoffersen CT, Englaro P, Heinze E, Rascher W, Teller W, Tonqvist H, Hauner H (1996) Insulin and cortisol promote leptin production in cultured human fat cells. Diabetes 45:1435-1438.

Woods SC, Seeley RJ, Porte DJ, Schwartz MW (1998) Signals that regulate food intake and energy homeostasis. Science 280:1378-1383.

Zhang Y, Proenca R, Maffie M, Barone M, Leopold L, Friedman JM (1994) Positional cloning of the mouse obese gene and its human homologue. Nature 372:425-432. 